\title{
PERAN PEMERINTAH DAERAH DALAM PENANGGULANGAN KEMISKINAN MELALUI PROGRAM PENINGKATAN KETERAMPILAN DI KOTA MEDAN
}

\author{
Mutiara Sari Lubis ${ }^{1}$, Irsyad Lubis ${ }^{2}$ \\ ${ }^{1}$ Prodi Ilmu Ekonomi, Universitas Sumatera Utara \\ ${ }^{2}$ Prodi Ilmu Ekonomi, Universitas Sumatera Utara \\ Corresponding email: Mutiarasarilubis@gmail.com
}

\begin{abstract}
Since 2015 the local government of Medan City has determined that poverty alleviation and community empowerment efforts become one of the regional priority programs. This program is contained in Medan City Regulation No. 5 of 2015. This study aims to determine the role of the City Government in poverty reduction through the Skills Improvement program in Medan and the factors that influence it. To achieve these objectives, qualitative research methods are used to decipher data descriptively. Data collection techniques are done by observation, interviews, and documents and archives using qualitative descriptive analysis techniques. The results showed: First, the role of the government in empowering the poor through the Skills Improvement program can be broadly categorized into two roles, namely the growth of the business climate and the strengthening of business potential or power. The growth of the business climate includes funding, facilities \& infrastructure, business information, business licensing and trade promotions. While Strengthening Potential or Power covers production and processing, marketing, and human resources. Second, the factors that influence the empowerment of the poor through the Skills Improvement program in Medan include inhibiting and supporting factors. The inhibiting factor is the lack of innovation in marketing and the limited budget which is only a few percent, while the supporting factors are human resources and abundant natural resources.
\end{abstract}

\section{Key word: Poverty Alleviation, Programs, Skills Improvement}

\section{PENDAHULUAN}

Pemerintah merupakan salah satu unsur yang berperan penting dalam mencapai tujuan suatu negara. Proses pencapaian tujuan bagi setiap negara pada dasarnya sama walaupun berbeda dalam rumusannya. Tujuan Negara Republik Indonesia sendiri tertuang dalam Pembukaan Undang-Undang Dasar (alinea ke IV) yaitu melindungi segenap bangsa dan seluruh tumpah darah Indonesia, memajukan kesejahteraan umum, mencerdaskan kehidupan bangsa, dan ikut melaksanakan ketertiban dunia yang berdasarkan kemerdekaan, perdamaian abadi, dan keadilan sosial.

Namun permasalahan senantiasa hadir di tengah masyarakat Indonesia salah satunya permasalahan sosial yaitu kemiskinan. Akan tetapi permasalahan kemiskinan bukan hanya terjadi di Indonesia, ini juga terjadi di Negara-negara berkembang lainnya. Kemiskinan sendiri adalah keadaan dimana terjadi ketidakmampuan untuk memenuhi kebutuhan dasar seperti makanan, pakaian, tempat berlindung, pendidikan, dan kesehatan.

Kemudian pemerintah mengupayakan berbagai stretegi dan program yang bertujuan untuk menanggulangi kemiskinan tersebut. Salah satunya adalah melalui Tim Nasional Percepatan Penanggulangan Kemiskinan (TNP2K) dimana ada empat strategi dasar yang telah ditetapkan dalam melakukan percepatan penanggulangan kemiskinan, yaitu : Menyempurnakan program perlindungan sosial, Peningkatan akses masyarakat miskin terhadap pelayanan dasar, Pemberdayaan masyarakat, dan Pembangunan yang inklusif

Secara umum, Usaha Mikro, Kecil dan Menengah merupakan kegiatan usaha yang dapat memperluas lapangan pekerjaan serta memberikan pelayanan ekonomi secara luas kepada masyarakat dan dapat berperan dalam proses pemerataan dan 
peningkatan pendapatan masyarakat, mendorong pertumbuhan ekonomi, serta berperan mewujudkan stabilitas nasional.

Undang Undang Nomor 20 tahun 2008 tentang Usaha Mikro, Kecil dan Menengah, pasal 2 menyatakan bahwa tujuan dunia usaha ini dalam rangka membangun perekonomian nasional berdasarkan demokrasi ekonomi yang berkeadilan. Pembangunan nasional diselenggarakan oleh rakyat dan pemerintah, dengan rakyat sebagai aktor yang vital perannya untuk pembangunan atau disebut pelaku utama pembangunan.

Di Kota Medan, Masalah Kemiskinan merupakan hal yang perlu untuk di atasi. Berdasarkan data dari susenas, kemiskinan di Kota Medan dalam 5 tahun terakhir yakni dari tahun 20122016 mengalami penurunan namun tidak terlalu signifikan. Berikut disajikan secara lengkap jumlah penduduk miskin di Kota Medan pada tahun 20122016 dalam tabel.

Jumlah masyarakat miskin di Kota Medan periode Tahun 2012- 2016, dengan memperhatikan serta menyimak secara teliti bahwa pergeseran angka garis kemiskinan dan persentase jumlah penduduk miskin di Kota Medan boleh dikatakan hampir tidak mengalami perubahan yang cukup berarti. Dengan membandingkan angka persentase penduduk miskin keadaan 5 tahun terakhir yaitu pada Tahun 2012 dan Tahun 2016, boleh dikatakan bahwa angka tersebut menunjukkan perubahan menguntungkan atau sedikit lebih baik karena mengalami penurunan sekitar 1,64 persen dari angka 10,22 pada tahun 2012 menurun menjadi 8,58 persen pada tahun 2016. Hal ini tentu merupakan indikator yang menunjukkan kerberhasilan pemerintah pusat dan daerah dalam melaksanakan berbagai program pengetasan 1 . kemiskinan di wilayah Kota Medan baik program yang menyentuh langsung rumah tangga penerima manfaat maupun program percepatan pembangunan infrastruktur daerah.

Sejak tahun 2015 pemerintah daerah Kota Medan telah menetapkan upaya pengetasan kemiskinan dan 2. pemberdayaan masyarakat menjadi salah satu program prioritas daerah. Program ini dilaksanakan berdasarkan Peraturan Daerah Kota Medan No. 5 Tahun 2015.

Berangkat dari masalah diatas, salah satu Program Pemerintah dalam pengetasan kemiskinan dan pemberdayaan masyarakat, yakni melalui program Peningkatan Keterampilan. Adapun program ini awalnya dibawahi langsung oleh Dinas Koperindag namun pada tahun 2017 Dinas Koperindag terbagi menjadi 3 dinas yaitu Dinas Koperasi, Dinas Perindustrian dan Dinas Perdagangan. Kemudian diambil alih oleh Dinas
Perindustrian namun tetap ada kordinasi antara Dinas Koperasi, Dinas Perdagangan dan beberapa lembaga-lembaga pemerintah kota lainnya.

Peningkatan Keterampilan disini termasuk dalam kategori usaha mikro, kecil dan menengah (UMKM). Salah satu kegiatan peningkatan keterampilan adalah kegiatan home industri atau rumah usaha produk atau juga perusahaan kecil. Dikatakan sebagai perusahaan kecil karena jenis kegiatan ekonomi ini dipusatkan di rumah. Pengertian usaha kecil secara jelas tercantum dalam UU No. 9 Tahun 1995, yang menyebutkan bahwa usaha kecil adalah usaha dengan kekayaan bersih paling banyak Rp200 juta (tidak termasuk tanah dan bangunan tempat usaha) dengan hasil penjualan tahunan paling banyak Rp1.000.000.000.

Kriteria lainnya dalam UU No 9 Tahun 1995 adalah: milik WNI, berdiri sendiri, berafiliasi langsung atau tidak langsung dengan usaha menengah atau besar dan berbentuk badan usaha perorangan, baik berbadan hukum maupun tidak. Home Industri juga dapat berarti industri rumah tangga, karena termasuk dalam kategori usaha kecil yang dikelola keluarga.

Berdasarkan realitas dan penjelasan diatas merupakan suatu hal yang menarik bagi penulis mengkaji lebih jauh dengan mengangkat judul penelitian, "Peran Pemerintah Daerah Dalam Penanggulangan Kemiskinan Melalui Program Peningkatan Keterampilan di kota Medan”.

\section{TINJAUAN TEORITIS}

\section{Pemerintah dan Pemerintah Daerah}

Dalam Undang-Undang Republik Indonesia Nomor 23 Tahun 2014 Tentang Pemerintahan Daerah dikatakan bahwa :

Pemerintah Pusat adalah Presiden Republik Indonesia yang memegang kekuasaan pemerintahan negara Republik Indonesia yang dibantu oleh Wakil Presiden dan menteri sebagaimana dimaksud dalam Undang-Undang Dasar Negara Republik Indonesia Tahun 1945.

Pemerintah Daerah adalah kepala daerah sebagai unsur penyelenggara Pemerintahan Daerah yang memimpin pelaksanaan urusan pemerintahan yang menjadi kewenangan daerah otonom.

Dalam melakukan otonomi daerah perlu asas yang harus dijalankan sebagai berikut, yaitu : Desentralisasi, Tugas pembantuan, Secara formal, Fungsi-fungsi pemerintahan yang dijalankan.

\section{$\underline{\text { Kemiskinan }}$}

Kemiskinan merupakan konsep yang berwayuh wajah, bermatra multidimensional. Ellis (1984:242245), misalnya, menunjukkan bahwa dimensi kemiskinan menyangkut aspek ekonomi, politik dan social- psikologis.Secara ekonomi, kemiskinan dapat 
didefinisikan sebagai kekurangan sumber daya yang dapat digunakan untuk memenuhi kebutuhan hidup dan meningkatkan kesejahteraan sekelompok orang. Ukuran Kemiskinan

Menurut BPS (Badan Pusat Statistik), tingkat kemiskinan didasarkan pada jumlah rupiah konsumsi berupa makanan yaitu 2100 kalori per orang per hari (dari 52 jenis komoditi yang dianggap mewakili pola konsumsi penduduk yang berada dilapisan bawah), dan konsumsi nonmakanan (dari 45 jenis komoditi makanan sesuai kesepakatan nasional dan tidak dibedakan antara wilayah pedesaan dan perkotaan).

\section{Pemberdayaan}

Wuradji dalam bukunya „Metodologi Pengembangan masyarakat. hal.3. mengatakan bahwa :"pemberdayaan adalah sebuah proses penyadaran masyarakat yang dilakukan secara transformative, partisipatif dan berkesinambungan melalui peningkatan kemampuan dalam menangani berbagai persoalan dasar yang dihadapi dan meningkatkan kondisi hidup sesuai dengan harapan". Dan masih banyak pendapat lain tentang pengertian pemberdayaan ini, diantaranya: Priyono dan Pranaka, dalam bukunya Priyono, Onny dan Pranaka, A.M.W, Hikmat, R. Harry dan Mubyarto, dalam bukunya, Sun ${ }^{e e} a n$, Muammil \& Abdurrahman Senuk. Ekonomi Pembangunan Daerah.

\section{Program Peningkatan Keterampilan}

\section{Home Industri}

Home berarti rumah, tempat tinggal, ataupun kampung halaman. Sedang Industri, dapat diartikan sebagai kerajinan, usaha produk barang dan ataupun perusahaan. Singkatnya, Home Industri (atau biasanya ditulis/dieja dengan "Home Industri") adalah rumah usaha produk barang atau juga perusahaan kecil. Dikatakan sebagai perusahaan kecil karena jenis kegiatan ekonomi ini dipusatkan di rumah. Pengertian usaha kecil secara jelas tercantum dalam UU No. 9 Tahun 1995, yang menyebutkan bahwa usaha kecil adalah usaha dengan kekayaan bersih paling banyak Rp200 juta (tidak termasuk tanah dan bangunan tempat usaha) dengan hasil penjualan tahunan paling banyak Rp1.000.000.000. Kriteria lainnya dalam UU No 9 Tahun 1995 adalah: milik WNI, berdiri sendiri, berafiliasi langsung atau tidak langsung dengan usaha menengah atau besar dan berbentuk badan usaha perorangan, baik berbadan hukum maupun tidak. Home Industri juga dapat berarti industri rumah tangga, karena termasuk dalam kategori usaha kecil yang dikelola keluarga.

\section{Pelaku Home Industri}

Pada umumnya, pelaku kegiatan ekonomi yang berbasis di rumah ini adalah keluarga itu sendiri ataupun salah satu dari anggota keluarga yang berdomisili di tempat tinggalnya itu dengan mengajak beberapa orang di sekitarnya sebagai karyawannya. Meskipun dalam skala yang tidak terlalu besar, namun kegiatan ekonomi ini secara tidak langsung membuka lapangan pekerjaan untuk sanak saudara ataupun tetangga di kampung halamannya. Dengan begitu, usaha perusahaan kecil ini otomatis dapat membantu program pemerintah dalam upaya mengurangi angka pengangguran. Lagi, jumlah penduduk miskinpun akan berangsur menurun.

\section{Pusat Kegiatan Home Industri}

Sebagaimana nama kegiatan ekonomi ini, Home Industri pada umumnya memusatkan kegiatan di sebuah rumah keluarga tertentu dan biasanya para karyawan berdomisili di tempat yang tak jauh dari rumah produksi tersebut. Karena secara geografis dan psikologis hubungan mereka sangat dekat (pemilik usaha dan karyawan), memungkinkan untuk menjalin komunikasi sangat mudah.Dari kemudahan dalam berkomunikasi ini diharapkan dapat memicu etos kerja yang tinggi.Karena masingmasing merasa bahwa kegiatan ekonomi ini adalah milik keluarga, kerabat dan juga warga sekitar. Merupakan tanggung jawab bersama dalam upaya meningkatkan perusahaan mereka.

\section{Home Industri sebagai Alternatif Penghasilan bagi Keluarga}

Bertambahnya jumlah keluarga tentu saja akan menambah jumlah kebutuhan dalam memenuhi keperluan anggota keluarga itu sendiri semakin meningkat. Kebutuhan keluarga ini akan terasa ringan terpenuhi jika ada usaha yang mendatangkan income atau penghasilan keluarga untuk menutupi kebutuhan tersebut. Home industri yang pada umunya berawal dari usaha yang turun menurun pada akhirnya ini meluas secara otomatis, dapat bermanfaat sebagai mata pencaharian bagi orangorang di kampung sekitarnya. Kegiatan ekonomi ini biasanya tidak begitu menyita waktu, sehingga memungkinkan pelaku usaha membagi waktunya untuk keluarga dan pekerjaan tetap yang diembannya.

\section{METODE PENELITIAN}

Lokasi penelitian ini dilaksanakan di Kota Medan dimana titik pengambilan data penelitian tentang program peningkatan keterampilan di, Kantor Walikota, Kantor Dinas Perindustrian, Kantor Dinas Koperasi UMKM, Kantor Dinas Sosial, Kantor Perusda, Tempat-tempat Home Industri. Tipe penelitian yang digunakan yakni kualitatif dengan penjabaran deskriptif. Teknik 
Pengambilan data dengan observasi dan wawancara dan dokumen dan arsip.

Informan pada penelitian ini adalah : Walikota Palopo, Kepala Dinas Perindustrian, Kepala Bidang Perindustrian, Kepala Bidang Koperasi UMKM, Kepala Bidang Dinas Sosial, Direktur Perusahan Daerah (Perusda) Kota Palopo dan Pelaku Home Industri.

\section{SIMPULAN DAN SARAN}

Peran pemerintah dalam pemberdayaan masyarakat miskin melalui program Pengembangan Keterampilan dapat dikategorisasi secara umum menjadi dua peran yaitu penumbuhan iklim usaha dan penguatan potensi atau daya usaha. Penumbuhan iklim usaha meliputi pendanaan, bantuan sarana \& prasarana kepada, penyebarluasan informasi usaha, kemudahan dalam perizinan usaha, serta bantuan promosi dagang. Penguatan Potensi atau Daya berupa pengembangan dalam bidang produksi dan pengolahan, pemasaran, sumber daya manusia serta desain dan teknologi. Semua upaya tersebut telah dilakukan oleh pemerintah Kota Medan meskipun belum sepenuhnya maksimal.

Pemerintah Daerah perlu meningkatkan kegiatan pemberdayaan peningkatan keterampilan yang telah dilakukan. Salah satu usaha yang perlu ditingkatkan yaitu dalam memberikan penyadaran akan pentingnya berwirausaha kepada masyarakat, memberikan pelatihan secara kreatif dan inovatif dengan melihat teknologi yang semakin canggih dan memanfaatkan potensi kearifan lokal serta sarana dan prasarana pemasaran seperti internet perlu dimanfaatkan dengan baik. Selain itu, Pemerintah daerah perlu membuat regulasi khusus terkait pemberdayaan masyarakat di Kota Medan seperti Peraturan Daerah atau Peraturan Walikota sehingga usaha yang dilakukan dapat optimal.

\section{HASIL PENELITIAN DAN PEMBAHASAN}

Tabel 1. Jumlah Penduduk Miskin dan Garis Kemiskinan di Kota Medan Tahun 2015-2019

\begin{tabular}{|c|c|c|c}
\hline Tahun & $\begin{array}{c}\text { Jumlah } \\
\text { Penduduk }\end{array}$ & $\begin{array}{c}\text { Jumlah Penduduk } \\
\text { Miskin }\end{array}$ & Persentase \\
\hline 2015 & 152573 & 15300 & 10,22 \\
\hline 2016 & 156603 & 14900 & 9,47 \\
\hline 2017 & 160819 & 15500 & 9,57 \\
\hline 2018 & 164903 & 14590 & 8,80 \\
\hline 2019 & 168.894 & 14.510 & 8,58 \\
\hline
\end{tabular}

Jumlah masyarakat miskin dan garis kemiskinan di Kota Medan periode Tahun 2015-2019, dengan memperhatikan serta menyimak secara teliti bahwa pergeseran angka garis kemiskinan dan persentase jumlah penduduk miskin di Kota Medan boleh dikatakan hampir tidak mengalami perubahan yang cukup berarti. Dengan membandingkan angka persentase penduduk miskin keadaan 5 tahun terakhir yaitu pada Tahun 2015 dan tahun 2019, boleh dikatakan bahwa angka tersebut meunjukkan perubahan menguntungkan atau sedikit lebih baik karena mengalami penurunan sekitar 1,64 persen dari angka 10,22 pada tahun 2015 menurun menjadi 8,58 persen pada tahun 2019 .

Tabel 2. Rata-rata Pengeluaran dan Persentase Rata-rata Pengeluaran Per Kapita Sebulan Menurut Kelompok Makanan di Kota Medan tahun 2019

\begin{tabular}{|c|c|c|}
\hline \multirow{2}{*}{ Jenis Bahan Makanan } & \multicolumn{2}{|c|}{ Rata- rata Konsumsi } \\
\hline & Satuan & Banyaknya \\
\hline Beras/ beras ketan & $\mathrm{Kg}$ & 1,697 \\
\hline Jagung basah dengan kulit & $\mathrm{Kg}$ & 0,022 \\
\hline Jagung pipilan/ beras jagung & $\mathrm{Kg}$ & 0,002 \\
\hline Ketela pohon/ singkong & $\mathrm{Kg}$ & 0,016 \\
\hline Ketela rambat/ ubi & $\mathrm{Kg}$ & 0,015 \\
\hline Ikan dan udang segar & $\mathrm{Kg}$ & 0,724 \\
\hline Ikan dan udang diawetkan & Ons/0.1 Kg & 0,210 \\
\hline Daging sapi & $\mathrm{Kg}$ & 0,008 \\
\hline Daging ayam ras/ kampung & $\mathrm{Kg}$ & 0,053 \\
\hline Telur ayam ras/ kampung & Butir/Unit & 1,938 \\
\hline Telur itik/manila & Butir/Unit & 0,147 \\
\hline Susu kental manis & 397 Grams & 0,104 \\
\hline Susu bubuk bayi & $\mathrm{Kg}$ & 0,031 \\
\hline Bawang merah & Ons/0.1 Kg & 0,322 \\
\hline Bawang putih & Ons/0.1 Kg & 0,212 \\
\hline Cabe merah & $\mathrm{Kg}$ & 0,005 \\
\hline Cabe rawit & $\mathrm{Kg}$ & 0,042 \\
\hline Tahu & $\mathrm{Kg}$ & 0,063 \\
\hline Tempe & $\mathrm{Kg}$ & 0,082 \\
\hline Minyak kelapa/goreng & Liter & 0,164 \\
\hline Kelapa & Butir/Unit & 0,057 \\
\hline Gula pasir & Ons/0.1 Kg & 1,293 \\
\hline Gula merah & Ons/0.1 Kg & 0,077 \\
\hline
\end{tabular}


Sumber : Hasil Olahan Sp Dinas Pertanian Kota Medan 2019

\section{Peran Pemerintah Daerah Dalam Pemberdayaan Masyarakat Miskin Melalui Program Peningkatan Keterampilan Di Kota Medan}

Pemberdayaan merupakan salah satu strategi pemerintah untuk mensejahterakan masyarakat khususnya di Kota Medan dimana untuk meningkatan taraf hidup masyarakat kurang mampu (miskin). melaui program unggulan yang di canangkan oleh pemerintah kota yakni Kegiatan Home Industri.

Home Industri (atau biasanya ditulis/dieja dengan "Home Industri") adalah rumah usaha produk barang atau juga perusahaan kecil. Dikatakan sebagai perusahaan kecil karena jenis kegiatan ekonomi ini dipusatkan di rumah. Pengertian usaha kecil secara jelas tercantum dalam UU No. 9 Tahun 1995, yang menyebutkan bahwa usaha kecil adalah usaha dengan kekayaan bersih paling banyak Rp200 juta (tidak termasuk tanah dan bangunan tempat usaha) dengan hasil penjualan tahunan paling banyak Rp1.000.000.000.

Kriteria lainnya dalam UU No 9 Tahun 1995 adalah: milik WNI, berdiri sendiri, berafiliasi langsung atau tidak langsung dengan usaha menengah atau besar dan berbentuk badan usaha perorangan, baik berbadan hukum maupun tidak. Home Industri juga dapat berarti industri rumah tangga, karena termasuk dalam kategori usaha kecil yang dikelola keluarga.

Dengan adanya Dinas Perindustrian di Kota Medan, maka peranan pemerintah daerah dalam mendukung pengembangan masyarakat miskin semakin nyata dan terlihat. Peranan Dinas Perindustrian tidak hanya dalam bentuk fisik, tetapi juga memberikan motivasi kepada pelaku usaha agar semakin giat mengembangkan usahanya. Hal ini sesuai wawancara dengan Kepala Bidang Pengembangan Teknologi Industri Kecil dan Menengah Bapak Drs. M. Amin Rambe bahwa : “ Pemerintah dalam hal ini dinas perindustrian telah melakukan upaya pemberdayaan masyarakat yang berpenghasilan rendah atau miskin yang kemudian dibina dan diberi keterampilan serta motivasi dengan cara memberikan bantuan peralatan dan terus meng follow up kegiatan-kegiatan agar mampu mengembangkan usahanya dan menciptakan produkproduk baru" (Wawancara pada tanggal 23 Mei 2019).

Sejalan dengan pendapat Ibu Suharni selaku Ketua Kelompok di Kec. Medan Tuntungan mengungkapkan bahwa, "Peranan Pemerintah Daerah sangat membantu dalam usaha saya. Awalnya kami dilatih dan dibina secara berkelompok, setelah berkelompok kita berusaha memproduksi tortilla (keripik) yang bahan bakunya dari ubi kayu, jagung dan rumput laut. (wawancara pada tanggal 8 juni 2019).

Tak hanya dalam bentuk pelatihan dan bantuan peralatan, teknis administrasi perizinan yang dilakukan pemerintah daerah diberi kemudahan dalam mengurusnya, hal ini sesuai dengan yang diungkapkan Kepala Bidang Pengembngan Teknologi Industri Kecil dan Menengah Bapak Drs. M. Amin Rambe bahwa : "izin usaha bagi pelaku usaha dimudahkan tanpa biaya sedikitpun atau secara gratis" (wawancara pada tanggal 23 Mei 2019).

Pemerintah Daerah Kota Medan memberikan bantuan cuma-cuma hanya kepada peserta program saja. Dengan kuantitas peserta program di Kota Medan menunjukkan kreatifitas masyarakat yang tinggi. Hal tersebut dilakukan untuk memenuhi kebutuhan hidup yang didukung oleh potensi alam yang ada. Kuantitas tersebut menjadikan kontribusi peserta program terhadap kesejahteraan masyarakat seperti pemerataan pendapatan, pengentasan kemiskinan, pertumbuhan ekonomi dan penciptaan lapangan kerja dinilai baik.

Selain itu, dengan adanya Program Peningkatan Keterampilan di Kota Medan dapat meningkatkan lapangan kerja, seperti yang disampaikan Ibu Suharni - , selaku Ketua Kelompok Khilan di kec. Medan Tuntungan: " kalau karyawannya adalah kebetulan Ibu Rumah Tangga yang berada di sekitar rumah yang rata-rata pekerjaannya jadi pemulung. Mereka tidak punya pekerjaan tetap, kemudian Ibu Suharni mengajak bergabung di usahanya." (wawancara pada tanggal 8 Juni 2019). Dampak-dampak sosial dari adanya kontribusi Program tersebut di atas tidak terlepas dari upaya-upaya pemberdayaan yang telah dilakukan sebelumya oleh Pemerintah Daerah Kota Medan. Secara teknis, pemberdayaan dapat dilakukan dengan melakukan penumbuhan iklim usaha dan penguatan potensi atau daya usaha.

\section{Peran Pemerintah Daerah dalam Menumbuhkan Iklim Usaha}

\section{Pendanaan}

Pemerintah Kota Medan menggunakan dana APBD untuk mengadakan program para peserta dalam dua gelombang yang dimana dalam satu gelombang terdiri dari 100 Orang dan dalam satu kelompok terdiri 
dari 10 orang, masing masing peserta mendapatkan 3.800.000 / orang selama 10 hari, dengan jumlah peserta sebanyak 200 orang dalam dua gelombang maka jumlah dana yang di keluarkan oleh pemerintah kota palopo dalam dua gelombang sebanyak 760.000 .000 .

Namun pemberian dana hanya pada proses pelatihan setelah itu tidak ada bantuan dana melainkan bantuan peralatan. Hal ini sesuai yang diungkapkan oleh Kepala Bidang Pengembngan Teknologi Industri Kecil dan Menengah Bapak Drs. M. Amin Rambe: "Bantuan dana hanya pada saat memberangkatkan peserta untuk dilatih tetapi bantuan peralatan masih ada hanya saja bantuan dana tidak ada lagi”. (wawancara pada tanggal 23 Mei 2019)

\section{Kemitraan}

Peranan Pemerintah daerah sangat penting dalam proses memitrakan pelaku usaha. Hasil Wawancara dengan Kepala Bidang Koperasi UMKM, Bapak Muhammad Azhar Lubis, bahwa :

"Peranan pemerintah daerah dalam hal ini dinas koperasi UMKM memudahkan segala urusan yang berkaitan dengan administrasi “ (Wawancara pada tanggal 31 Mei 2019). Adapun dari teknis pola kemitraanya Hasil wawancara dengan Kepala Kepala Bidang Koperasi UMKM, Bapak Muhammad Azhar Lubis mengungkapkan : "Pemerintah daerah dalam mengkordinasi kemitraan seperti misalnya pada saat ada pameran, Dinas Koperasi UMKM mencarikan mitra untuk para pelaku program, kalau ada yang berminat kita yang memfasilitasi mereka. Contoh pengurusan Administrasi antara pelaku program terhadap lembaga menjalin kemitraan dengan pelaku program. ada mitra yang mau mengambil/membeli produksinya, kita memfasilitasinya dengan mempertemukan mereka, Biasa ada juga yang langsung mencari mitra sendiri tidak melalui Dinas Koperasi UMKM." (Wawancara pada tanggal 31 Mei 2019).

\section{Perizinan Usaha}

Pemerintah memberikan kemudahan kepada pelaku usaha dalam urusan perizinan. Hal ini sesuai dengan yang diungkapkan Kepala Bidang Pengembngan Teknologi Industri Kecil dan Menengah Bapak Drs. M. Amin Rambe bahwa: "Dalam proses perizinan bagi para pelaku program pemerintah sendiri memberikan kemudahan dan secara gratis, dalam hal ini dinas perindustrian sendiri mengeluarkan surat rekomendasi usaha bagi pelaku program yang kemudian ditindak lanjuti oleh Dinas Penanaman Modal Pelayanan
Terpadu satu Pintu untuk dikeluarkannya surat izin usaha industri (SIUI)." (wawancara pada tanggal 23 Mei 2019)

Sejalan dengan pendapat di atas, Hasil wawancara dengan Ibu Ratnawati kendek selaku ketua kelompok Kec.Medan Kota, bahwa dalam pengalamannya mengurus surat izin usaha sangat mudah dan pembiayaannya gratis.

"Perizinan usaha lancar, prosesnya kalau mau bikin surat izin usaha itu dimudahkan dan biayanya pun gratis tidak di bayar." (Wawancara pada tanggal 9 Juni 2019).

\section{Produksi dan Pengolahan}

Pemberian bantuan peralatan diberikan melalui kelompok. Pemerintah daerah tidak memberikan bantuan pada usaha perorangan. Seperti yang diungkapkan Kepala Bidang Pengembngan Teknologi Industri Kecil dan Menengah Bapak Drs. M. Amin Rambe bahwa, "kita beri bantuan peralatan, Itu sudah banyak terlaksana. Tapi itu bukan diberi secara perorangan tapi melalui kelompok. Namun harus membuat permohonan. Kelompok itu, maksudnya terdiri dari beberapa orang di dalamnya, dan mempunyai badan pengurus." (Wawancara pada tanggal 23 Mei 2019)

Hal ini sesuai dengan hasil wawancara ibu suharni selaku ketua kelompok di kec. Medan Tuntungan bahwa : "kalau untuk standarisasi kami memberi bantuan sertifikat halal untuk produk Khilan ada dua produk yang sudah di beri sertifikat halal yaitu tortilla jagung dan rumput laut semuanya di berikan secara cuma-cuma gratis." (Wawancara pada tanggal 8 Juni 2019).

\section{DAFTAR PUSTAKA}

[1] Blanchard, Ken.et. al. (2004).Pemberdayaa Memerlukan Waktu Lebih dari Satu Menit. Batam Centre: Interaksara.

[2] Edi, Suharto. (2010).Membangun Masyarakat Memberdayakan Rakyat. Bandung: Refika Aditama.

[3] Hikmat, R. Harry. (2001).Strategi Pemberdayaan Masyarakat. Bandung: Humaniora Utama Press.

[4] Labolo, Muhadam. (2014).Memahami Ilmu Pemerintahan suatu kajian, teori, konsep dan pengembangannya. Jakarta: Rajawali Pers. 
[5] Priyono, Onny dan Pranarka, A.M.W. (1996).Pemberdayaan : Konsep, Kebijakan dan Implementasi. Jakarta: Center for Strategic and Internasional Studies (CSIS).

[6] Rasyid, Ryaas. (2000).Makna Pemerintahan: Tinjauan dari segi etika dan kepemimpinan. Jakarta: PT. Mutiara Sumber Widya.

[7] Sabarno, Hari. (2008).Memandu Otonomi Daerah Menjaga Kesatuan Bangsa. Jakarta: Sinar Grafika.

[8] Sufianto, Dadang. (2016). Etika
Pemerintahan di
Indonesia.

Bandung:Alfabeta.

[9] Syafiie, Inu Kencana. (2013).Ilmu Pemerintahan. Jakarta: Bumi Aksara. Syafiie, Inu Kencana. (2013).Ilmu Pemerintahan Edisi Revisi Kedua. Bandung: Mandar Maju.

[10] Syaukani.et. al. (2009).Otonomi Daerah dalam Negara Kesatuan. Yogyakarta: Pustaka Pelajar.

[11] Wuradji. (2009).Metodologi Pengembangan masyarakat. Yogyakarta: Teras.

[12] Zubaedi. (2007).Wacana Pengembangan Alternatif: Ragam Perspektif Pengembangan dan Pemberdayaan Masyarakat. Yogyakarta: Ar- Ruzz Media. 